\title{
RECENT PATTERNS IN DOWNWARD INCOME MOBILITY: SINKING BOATS IN A RISING TIDE
}

(Accepted June 20, 1993)

\begin{abstract}
This paper employs four measures of downward income mobility and 1984-1986 PSID data to examine the extent and possible causes of downward mobility. Despite modest economic growth during this period, a substantial number of Americans experienced downward income mobility, roughly $5 \%$ to $20 \%$. The majority of the downwardly mobile initially lived with a nonelderly, Caucasian, male, lesseducated, working household head. Logit analysis indicates that the following factors significantly increase the odds of downward income mobility: Male headship; minority headship; family dissolution; nest-leaving; and having a head who works in mining, construction, manufacturing, transportation, trade, or farming. The following factors significantly lower the odds of downward income mobility: Retaining the same household head; having a college-educated head; having a head who works in a professional, technical, or operative occupation; and having a head in the finance, insurance, and real estate industry.
\end{abstract}

\section{INTRODUCTION}

Americans have generally assumed that their economic status would "naturally" increase over time. From World War II until the early 1970s upward mobility was indeed a realistic expectation: Wages grew by $2.5 \%$ to $3 \%$ annually and real median family income doubled (Levy, 1987). Furthermore, families throughout the income distribution enjoyed these gains. ${ }^{1}$ Since 1973 , however, real wage growth has slowed to the point of stagnation and family income has grown more unequal. In the $1980 \mathrm{~s}$ the growth in the inequality of wages, earnings, and family income accelerated (Levy and Murnane, 1992; Karoly, 1993). These trends have begun to make their mark on Americans" sense of economic well-being. Academics and the popular press express concern that the middle class is disappearing (e.g., Thurow, 1987 and Strobel, 1993) and that the "American Dream" is vanishing (e.g., Dentzer, 1991). The prospects for upward income mobility seem to be dimming and Americans have begun to fear downward mobility. Did the changes in the growth and the dispersion of wages, earnings, and family income 
merely slow the pace of upward mobility or have many Americans actually become downwardly mobile?

On a personal level, downward income mobility inflicts both material and psychological hardship (Ehrenreich, 1989; Newman, 1988). On a policy level, many of the downwardly mobile become eligible for government assistance, increasing the claims on strained public resources. More importantly, the downwardly mobile reduce their consumption, savings, and investment. Such cuts by a significant proportion of the population could dampen overall economic growth.

During the seventies and eighties economists and sociologists conducted many studies of poverty, but relatively few of the broader problem of downward income mobility. Duncan (1988) and Burkhauser and Duncan (1989) present the only detailed analyses of downward income mobility. Both studies identify an individual as downwardly mobile if their family income-to-needs ratio fell by $50 \%$ or more at least once during the decade of analysis. Duncan and Burkhauser examine the relationship between downward mobility and age, gender, and "life events" (e.g., divorce and unemployment).

The present study also uses large drops in the income-to-needs ratio to identify the downwardly mobile. We also examine the connection between downward income mobility and many of the same factors considered by the earlier research, for example changes in family composition. In this sense, this paper updates the work of Burkhauser and Duncan. However, this study also expands upon their work. In addition to large drops in the income-to-needs ratio, we also use drops down the quintile distribution of real family income to measure downward mobility. Furthermore, this paper expands the analysis of the factors associated with downward income mobility to include race, education, region, occupation and industry.

The previous studies cover more years and thus include the effects of the business cycle. We examine downward mobility over a short time period, 1984 to 1986 . This shorter period controls for business cycle effects by focusing on one part of a cycle: An upturn. Many have considered whether a rising tide will lift all boats, we instead examine whether a rising tide keeps boats from sinking.

The paper is organized as follows. Section I reviews the literature on downward income mobility. The second section describes the data and 
methodology. The next section reviews the recent trends in the distribution of wages, earnings, and family income. These trends may suggest which groups are likely to be downwardly mobile. Section IV examines the characteristics of the downwardly mobile and contrasts them with the characteristics of the entire sample. Section V reports the frequency, or risk, of downward income mobility overall and then by demographic groups. The sixth section presents Logit analysis of the factors which significantly influence the likelihood of downward income mobility.

The results show that a substantial minority of Americans, roughly $5 \%$ to $20 \%$ depending on the specific measure, were downwardly mobile during the period 1984-1986 even though the economy experienced modest growth. The majority of the downwardly mobile lived in 1984 households headed by a nonelderly, Caucasian, married, working man. Individuals living in households whose head was male, a minority, unemployed, lacked a college education, or became the head of the household during the sample period face higher risks of downward income mobility.

\section{LITERATURE REVIEW}

Duncan et al. (1984) spend one chapter examining family income mobility over the period 1971-1978. They find substantial mobility throughout the quintile distribution of family income. Of particular interest, $31.3 \%$ of the sample individuals dropped at least one quintile and $11.3 \%$ dropped two or more quintiles over the sample period. Duncan (1988) examines downward mobility in terms of drops of $50 \%$ or more in the real family income-to-needs ratio at least once during the period 1969-1979. He finds that approximately one-third of the sample individuals were downwardly mobile during this decade (Table I).

Duncan (1988) focuses on eight major "life events" as likely causes of downward income mobility. Downward mobility was most frequently associated with: (1) becoming a household head or wife; (2) a decrease in hours worked by other family members; and (3) the household head becoming unemployed. Downward mobility was more frequent among those in the retirement and "nest leaving" cohorts. Lastly, the risk for 
TABLE I

Summary of previous findings

\begin{tabular}{|c|c|c|c|}
\hline Study & $\begin{array}{l}\text { Study } \\
\text { Period }\end{array}$ & $\begin{array}{l}\text { Downward Mobility } \\
\text { Measure }\end{array}$ & $\begin{array}{l}\text { Percent } \\
\text { Downwardly Mobile }\end{array}$ \\
\hline $\begin{array}{l}\text { Duncan, } \\
\text { Smeeding, } \\
\text { Rodgers } \\
\text { (1991) }\end{array}$ & $1967-79$ & $\begin{array}{l}\text { Movement to a lower } \\
\text { class ( } 3 \text { classes) }\end{array}$ & $\begin{array}{l}29.7 \% \text { of upper } \\
\text { fell to middle } \\
6.2 \% \text { of middle } \\
\text { fell to lower }\end{array}$ \\
\hline $\begin{array}{l}\text { Duncan } \\
\text { (1988) }\end{array}$ & $1969-79$ & $\begin{array}{l}\text { Drops in real family } \\
\text { income-to-needs ratio } \\
\text { of } 50 \% \text { or more }\end{array}$ & $33 \%$ \\
\hline $\begin{array}{l}\text { Duncan } \\
\text { et al. } \\
\text { (1984) }\end{array}$ & $1971-78$ & $\begin{array}{l}\text { Movement down the } \\
\text { quintile distribution } \\
\text { of real family income }\end{array}$ & $\begin{array}{l}31.3 \% \text { dropped } \\
\text { at least } 1 \\
\text { quintile } \\
11.3 \% \text { dropped } \\
\text { at least } 2 \\
\text { quintiles }\end{array}$ \\
\hline $\begin{array}{l}\text { Burkhauser } \\
\text { and Duncan } \\
\text { (1989) }\end{array}$ & $1974-83$ & $\begin{array}{l}\text { Drops in real family } \\
\text { income-to-needs ratio } \\
\text { of } 50 \% \text { or more }\end{array}$ & $25 \%$ \\
\hline $\begin{array}{l}\text { Duncan, } \\
\text { Smeeding, } \\
\text { Rodgers } \\
\text { (1991) }\end{array}$ & $1980-86$ & $\begin{array}{l}\text { Movement to a lower } \\
\text { class ( } 3 \text { classes) }\end{array}$ & $\begin{array}{l}27.1 \% \text { of upper } \\
\text { fell to middle } \\
8.5 \% \text { of middle } \\
\text { fell to lower }\end{array}$ \\
\hline
\end{tabular}

women was either the same or higher than that of men in all age cohorts.

Burkauser and Duncan (1989) use the same measure to examine life-cycle patterns of downward income mobility during the period 1974-1983. They find that from age 26 to 65 women face a higher risk of downward mobility than do men. The risk for women is highest (34\%) for the age 46 to 55 cohort. Men in the age 66 and older cohort face the highest male risk ( $31 \%$ ).

The authors also find that the link between downward mobility and family composition changes is stronger for women than for men. Divorce, death of a spouse, and the birth of a child seem most strongly associated with women's downward mobility. Labor market events, 
however, appear to have similar impacts on both genders. Downward mobility is most strongly associated with the head's unemployment for the 26 to 45 years old cohort and loss of hours due to retirement or disability for the 46 to 65 years old cohort.

The most recent study which examines downward income mobility does so within the context of overall class mobility. Duncan, Smeeding, and Rodgers (1991) examine movement between three classes over the periods 1967-1979 and 1980-1986. They define the upper class as individuals whose real family income-to-needs ratio is at least 6 . The lower class is defined by a ratio of 2 or less. The middle class has income-to-needs ratios between 2 and 6 . Drops from the upper class and drops from middle class constitute downward mobility in this study.

The authors find that drops from the upper to the middle class became less frequent in the eighties than in the earlier period. However, drops from the middle to the lower class became more frequent. Younger families were more likely to drop from the upper to the middle class. African-Americans and female-headed households were more likely to fall from the middle class.

\section{DATA AND METHODOLOGY}

The data consist of persons present in the 1984 through 1987 interviewing waves of the Panel Study of Income Dynamics (PSID). The 1986 and 1984 interviewing waves contain demographic information for 1986 and 1984 respectively. The 1987 and 1985 interviewing waves contain information on income in the years 1986 and 1984 respectively. Each observation is weighted by the 1987 individual probability weight. ${ }^{2}$

The analysis uses four measures of downward income mobility. Drops of one-third or more and drops of one-half or more in the real family income-to-needs ratio identify persons as absolutely downwardly mobile..$^{3}$ Drops of at least one quintile and drops of two or more quintiles in the distribution of real family income identify persons as relatively downwardly mobile. ${ }^{4}$

Note that downward income mobility in terms of any of these four measures does not necessarily imply poverty. Furthermore, absolute 
and relative downward mobility may be driven by different forces. For example, assuming family size remains constant, if the mean of the family income distribution shifts downward, but the variance remains the same, we would observe absolute, but not relative downward mobility.

Because family composition often changes the unit of analysis is the individual. To determine if an individual is downwardly mobile in the absolute sense, for example, we look at the real family income-to-needs ratio of the family of which the person was a member in 1984 and compare that to the ratio of the family of which the person is a member in 1986.

\section{RECENT TRENDS IN WAGES, EARNINGS, AND FAMILY INCOME}

Labor income accounts for the majority of family income, thus adverse changes in the labor market will contribute to downward mobility. Duncan, Smeeding, and Rodgers (1991) find that male earnings in particular play a major role in all class transitions. During the eighties the distribution of wages and earnings changed in ways likely to contribute to the downward income mobility of various groups.

The growth in median wages for all workers began slowing in 1973 and has been fairly stagnate ever since. Juhn, Murphy, and Pierce (1990) report that the average weekly male wage actually fell by about $5 \%$ from 1970 to 1987 . Also troubling is the acceleration of the growth in wage inequality, especially among men (Levy and Michel, 1991; Katz and Murphy, 1992). During the eighties low-wage male workers saw their average wage fall faster than other men's and faced increased unemployment. The college education premium grew rapidly, leaving less-educated men with diminished opportunities in comparison (Levy and Murnane, 1992; Katz and Murphy, 1992; Bound and Johnson, 1992; Burtless, 1990). Furthermore, the wages of younger, less-educated workers declined relative to the wages of their older counterparts. These developments suggest that, ceteris paribus, younger, less-educated men and their dependents are more likely to be both absolutely and relatively downwardly mobile.

Women's wages have generally increased over the last decade, 
closing the male-female wage gap somewhat (Katz and Murphy, 1992; Karoly, 1993). This trend suggests that, ceteris paribus, women may be less likely than men to be either absolutely or relatively downwardly mobile. Karoly (1993) also finds that during the 1980s wages for lowwage women declined while the wages of high-wage women increased at a greater rate. Thus, low-wage and less-educated workers of both genders may face a higher risk of both absolute and relative downward income mobility.

The distribution of earnings exhibits similar patterns: Overall stagnation accompanied by accelerating inequality (Karoly, 1993; Levy and Murnane, 1992). Median family income has grown slightly since 1979 and the average family income-to-needs ratio increased by approximately 10\% from 1978 to 1988 (Burtless, 1991). Cancian et al. (1993) find that the largest portion of the rise in family income results from increased wives' earnings. However, the growth in family income has occurred mostly at the top of the distribution. From 1978 to 1988 the family income-to-needs ratio of those in the 90 th percentile rose by about $23 \%$ while the ratio of those in the 10 th percentile fell by $6.5 \%$ (Burtless, 1991).

Increasing family income inequality itself is not a new phenomenon, but its acceleration is (Levy and Michel, 1991; Karoly, 1993). Also new is the failure of family income inequality to diminish during a period of economic recovery. Cancian, Danziger, and Gottschalk (1993) find that the rise in inequality from 1968 to 1989 is due in large part to increased inequality in husbands' earnings. They also report that approximately one-third of the increase in family income inequality results from changes in family headship.

These trends suggest that families towards the bottom of the distribution may be more at risk of absolute downward mobility than are families at the top. In addition, individuals whose family changes headship (through divorce, for example) may be more at risk of both absolute and relative downward mobility.

\section{CHARACTERISTICS OF THE DOWNWARDLY MOBILE}

Table II reports the characteristics of the sample and of the absolutely downwardly mobile. The sample contains 264,849 probability weighted 
TABLE II

Characteristics of the absolutely downwardly mobile

\begin{tabular}{|c|c|c|c|}
\hline & Sample & $\begin{array}{l}\text { Income- } \\
\text { to-needs } \\
\text { fell by } \\
>33 \%\end{array}$ & $\begin{array}{l}\text { Income- } \\
\text { to-needs } \\
\text { fell by } \\
>50 \%\end{array}$ \\
\hline \multicolumn{4}{|l|}{$\begin{array}{l}\text { Gender of } 1984 \\
\text { household head: }\end{array}$} \\
\hline Female & $19.9 \%$ & $22.4 \%$ & $21.1 \%$ \\
\hline Male & $80.1 \%$ & $77.6 \%$ & $78.9 \%$ \\
\hline \multicolumn{4}{|l|}{$\begin{array}{l}\text { Age of } 1984 \\
\text { household head: }\end{array}$} \\
\hline $\begin{array}{l}64 \text { or younger } \\
65 \text { or older }\end{array}$ & $\begin{array}{l}88.1 \% \\
11.9 \%\end{array}$ & $\begin{array}{l}89.1 \% \\
10.9 \%\end{array}$ & $\begin{array}{l}89.4 \% \\
10.6 \%\end{array}$ \\
\hline $\begin{array}{l}34 \text { or younger } \\
35 \text { or older }\end{array}$ & $\begin{array}{l}33.6 \% \\
66.4 \%\end{array}$ & $\begin{array}{l}32.8 \% \\
67.2 \%\end{array}$ & $\begin{array}{l}33.5 \% \\
66.5 \%\end{array}$ \\
\hline \multicolumn{4}{|l|}{$\begin{array}{l}\text { Race of } 1984 \\
\text { household head: }\end{array}$} \\
\hline Caucasian & $84.3 \%$ & $77.9 \%$ & $78.2 \%$ \\
\hline Afro-American & $12.2 \%$ & $16.4 \%$ & $15.5 \%$ \\
\hline Other & $3.5 \%$ & $5.7 \%$ & $6.3 \%$ \\
\hline Child (under age & $19.5 \%$ & $19.0 \%$ & $19.8 \%$ \\
\hline \multicolumn{4}{|l|}{ Region in 1984: } \\
\hline Northeast & $22.1 \%$ & $20.1 \%$ & $19.7 \%$ \\
\hline $\begin{array}{l}\text { North Central } \\
\text { South }\end{array}$ & $\begin{array}{l}28.3 \% \\
31.3 \%\end{array}$ & $\begin{array}{l}21.8 \% \\
33.8 \%\end{array}$ & $\begin{array}{l}29.0 \% \\
32.7 \%\end{array}$ \\
\hline $\begin{array}{l}\text { Soutn } \\
\text { West }\end{array}$ & $17.8 \%$ & $17.4 \%$ & $17.9 \%$ \\
\hline $\mathrm{AK}, \mathrm{HI}$ & $0.3 \%$ & $0.5 \%$ & $0.6 \%$ \\
\hline Foreign & $0.3 \%$ & $0.5 \%$ & $0.0 \%$ \\
\hline \multicolumn{4}{|l|}{$\begin{array}{l}\text { Marital Status } \\
\text { of } 1984 \text { head: }\end{array}$} \\
\hline Married & $73.9 \%$ & $71.1 \%$ & $72.1 \%$ \\
\hline Single & $8.8 \%$ & $8.0 \%$ & $10.3 \%$ \\
\hline Widowed & $6.2 \%$ & $8.0 \%$ & $6.4 \%$ \\
\hline Divorced & $8.1 \%$ & $9.7 \%$ & $7.9 \%$ \\
\hline Separated & $3.1 \%$ & $3.2 \%$ & $3.3 \%$ \\
\hline \multicolumn{4}{|l|}{$\begin{array}{l}\text { Education Level } \\
\text { of } 1984 \text { head: }\end{array}$} \\
\hline Didn't finish HS & $25.4 \%$ & $29.2 \%$ & $31.8 \%$ \\
\hline High school only & $20.5 \%$ & $21.5 \%$ & $17.7 \%$ \\
\hline $\mathrm{HS}+$ training & $16.5 \%$ & $17.5 \%$ & $19.4 \%$ \\
\hline Some college & $18.2 \%$ & $15.7 \%$ & $16.3 \%$ \\
\hline College degree & $13.5 \%$ & $10.1 \%$ & $9.1 \%$ \\
\hline $\begin{array}{l}\text { Advanced/pro- } \\
\text { fessional degree }\end{array}$ & $6.0 \%$ & $6.0 \%$ & $5.8 \%$ \\
\hline
\end{tabular}




\begin{tabular}{|c|c|c|c|}
\hline & Sample & $\begin{array}{l}\text { Income- } \\
\text { to-needs } \\
\text { fell by } \\
>33 \%\end{array}$ & $\begin{array}{l}\text { Income- } \\
\text { to-needs } \\
\text { fell by } \\
>50 \%\end{array}$ \\
\hline \multicolumn{4}{|l|}{$\begin{array}{l}\text { Employment status of } \\
1984 \text { household head: }\end{array}$} \\
\hline Working & $75.2 \%$ & $72.8 \%$ & $73.7 \%$ \\
\hline Temp. not working & $0.8 \%$ & $1.9 \%$ & $0.9 \%$ \\
\hline Unemployed & $4.0 \%$ & $5,0 \%$ & $5.4 \%$ \\
\hline Retired & $11.4 \%$ & $9.7 \%$ & $8.8 \%$ \\
\hline Keeping house & $4.3 \%$ & $6.3 \%$ & $5.3 \%$ \\
\hline Disabled & $2.7 \%$ & $2.3 \%$ & $2.2 \%$ \\
\hline Student & $1.1 \%$ & $1.2 \%$ & $2.2 \%$ \\
\hline Workfare, jail, other & $0.4 \%$ & $0.8 \%$ & $1.6 \%$ \\
\hline \multicolumn{4}{|l|}{ Change in headship: } \\
\hline $\begin{array}{l}\text { Same head } \\
1984 \text { wife became }\end{array}$ & $91.4 \%$ & $82.2 \%$ & $78.0 \%$ \\
\hline 1986 head & $2.6 \%$ & $7.4 \%$ & $10.2 \%$ \\
\hline 1984 female head & & & \\
\hline became 1986 wife & $2.2 \%$ & $1.4 \%$ & $0.9 \%$ \\
\hline 1986 head was neither & & & \\
\hline head nor wife in 1984 & $3.3 \%$ & $7.3 \%$ & $10.3 \%$ \\
\hline Institutionalized husband & & & \\
\hline in 1984 returns by 1986 & $0.6 \%$ & $1.6 \%$ & $0.6 \%$ \\
\hline
\end{tabular}

Table reads: In 1984, 19.9\% of the sample individuals lived in female-headed households and $80.1 \%$ lived in male-headed households. Of those whose income-to-needs fell by onethird or more, $22.4 \%$ lived in female-headed households and $77.6 \%$ lived in male-headed households in 1984.

cases $(13,619$ unweighted observations). The majority of the absolutely downwardly mobile began the period in households headed by a nonelderly, Caucasian, married man with a high school or less education. Over $70 \%$ of the downwardly mobile lived with a household head who was working in 1984 , while $4 \%$ to $5 \%$ lived with an unemployed head. That so many of the downwardly mobile lived with less-educated, working men confirms the severity of the impact of the recent trends in the wages and earnings of unskilled men. The role of family composition changes makes no appearance here - most of the absolutely downwardly mobile lived in households headed by the same person over the sample period. In sum, the majority of the downwardly mobile lived in traditional, working families. 
Comparing the characteristics of the sample to the characteristics of the absolutely downwardly mobile shows which groups are disproportionately downwardly mobile. For example, persons living with a household head who did not have a high school degree in 1984 make up $25.4 \%$ of the sample, but account for $31.8 \%$ of those whose income-toneeds fell by $50 \%$ or more. Other groups which appear disproportionately downwardly mobile include those with a 1984 household head who was single or not Caucasian, and those who experienced a change in headship.

Those whose 1984 household head worked are only slightly underrepresented among the downwardly mobile, while those whose heads were unemployed, keeping house, or in school are somewhat overrepresented. The absolutely downwardly mobile appear to be distributed across regions much as is the general population.

This analysis does reinforce prior findings regarding the role of family composition. Those whose family retained the same head throughout the sample period and those whose 1984 female head married by 1986 are under-represented among the downwardly mobile. Those for whom the 1984 wife became the 1986 head are disproportionately downwardly mobile. Lastly, those persons whose 1986 family was headed by some one other than the 1984 head or wife are also disproportionately downwardly mobile. This last family composition change generally represents children leaving the nest to form their own families.

Table III reports the characteristics of the relatively downwardly mobile. This analysis includes only members of the third quintile in 1984. This restricted sample contains 52,953 probability weighted cases (2,580 unweighted observations). Analysis of quintile drops among all sample members produces questionable, if not misleading, results. For example, in the full sample female-headed households and African-Americans do not appear disproportionately relatively downwardly mobile. This result occurs largely because these groups disproportionately fill the lower quintile and have nowhere to fall.

The characteristics of the relatively downwardly mobile resemble those of the absolutely downwardly mobile with a few exceptions. First, the over-representation of persons whose household head was neither Caucasian nor African-American among those dropping two quintiles 
TABLE III

Characteristics of the relatively downwardly mobile

Persons

in third

quintile in

Fell 1

Fell 2

1984

quintile

quintiles

Gender of 1984

household head:

$\begin{array}{llll}\text { Female } & 12.8 \% & 12.8 \% & 20.6 \% \\ \text { Male } & 87.2 \% & 87.2 \% & 79.4 \%\end{array}$

Age of 1984

household head:

64 or younger

$92.1 \%$

$91.5 \%$

$87.1 \%$

65 or older

$7.9 \%$

$8.5 \%$

$12.9 \%$

34 or younger

$40.5 \%$

$35.8 \%$

$34.8 \%$

35 or older

$59.5 \%$

$65.2 \%$

Race of 1984

household head:

Caucasian

Afro-American

Other

$87.6 \%$

$9.6 \%$

$2.9 \%$

$64.2 \%$

Child (under age

14 in 1984)

$22.1 \%$

$87.1 \%$

$71.1 \%$

$11.2 \%$

$14.9 \%$

$1.7 \%$

$14.0 \%$

Region in 1984:

Northeast

North Central

$22.7 \%$

$28.9 \%$

South

$29.3 \%$

West

$18.6 \%$

AK,HI

$0.2 \%$

Foreign

$0.2 \%$

$18.0 \%$

$16.5 \%$

Marital Status

of 1984 head:

Married

$81.2 \%$

Single

$6.8 \%$

Widowed

$3.7 \%$

Divorced

$6.6 \%$

Separated

$1.7 \%$

$21.6 \%$

$26.4 \%$

$11.6 \%$

$33.4 \%$

$31.4 \%$

$18.5 \%$

$0.0 \%$

$0.0 \%$

$23.7 \%$

$1.1 \%$

$0.0 \%$

Education level

of 1984 head:

Didn't finish HS

$19.3 \%$

$22.9 \%$

$81.0 \%$

$71.1 \%$

$5.0 \%$

$3.6 \%$

$4.6 \%$

$7.4 \%$

$7.0 \%$

$15.7 \%$

$2.4 \%$

$2.2 \%$

High school only

$20.9 \%$

HS + training

$21.0 \%$

College degree

$10.9 \%$

$28.0 \%$

$31.7 \%$

$31.1 \% \quad 20.8 \%$

$13.4 \%$

$24.3 \%$

$20.0 \%$

$16.7 \%$

Advanced/pro-

$5.5 \%$

$1.8 \%$

fessional degree

$5.0 \%$

$1.9 \%$

$4.6 \%$ 
Table III (Continued)

\begin{tabular}{|c|c|c|c|}
\hline & $\begin{array}{l}\text { Persons } \\
\text { in third } \\
\text { quintile in } \\
1984\end{array}$ & $\begin{array}{l}\text { Fell 1 } \\
\text { quintile }\end{array}$ & $\begin{array}{l}\text { Fell } 2 \\
\text { quintiles }\end{array}$ \\
\hline \multicolumn{4}{|l|}{ Employment status of } \\
\hline Working & $82.9 \%$ & $84.4 \%$ & $76.2 \%$ \\
\hline Temp, not working & $1.1 \%$ & $0.5 \%$ & $4.6 \%$ \\
\hline Unemployed & $1.9 \%$ & $0.7 \%$ & $4.3 \%$ \\
\hline Retired & $9.9 \%$ & $11.5 \%$ & $5.6 \%$ \\
\hline Keeping house & $1.0 \%$ & $0.4 \%$ & $3.3 \%$ \\
\hline Disabled & $2.1 \%$ & $2.5 \%$ & $2.1 \%$ \\
\hline Student & $0.7 \%$ & $0.0 \%$ & $1.3 \%$ \\
\hline Workfare, jail, other & $0.4 \%$ & $0.0 \%$ & $2.6 \%$ \\
\hline \multicolumn{4}{|l|}{ Change in headship: } \\
\hline \multirow{2}{*}{\multicolumn{4}{|c|}{$\begin{array}{l}\text { Same head } \\
1984 \text { wife became }\end{array}$}} \\
\hline & & & \\
\hline 1986 head & $1.2 \%$ & $2.9 \%$ & $6.6 \%$ \\
\hline 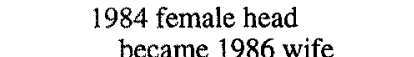 & $21 \%$ & $25 \%$ & 020 \\
\hline 1986 head was neither & & & \\
\hline head nor wife in 1984 & $2.8 \%$ & $2.6 \%$ & $16.5 \%$ \\
\hline Institutionalized husband & & & \\
\hline in 1984 returns by 1986 & $0.2 \%$ & $0.3 \%$ & $0.2 \%$ \\
\hline
\end{tabular}

Table reads: Of those persons in the third quintile in 1984, $87.2 \%$ lived in male-headed households in 1984 and $12.8 \%$ lived in female-headed households. Of those who fell two quintiles, $79.4 \%$ lived in male-headed households and $20.6 \%$ in female-headed households in 1984.

appears much more pronounced. Second, the regional distribution of the relatively downwardly mobile does not match the entire subsample's distribution as closely. Specifically, individuals living in the Northeast appear under-represented among the relatively downwardly mobile. Persons in the South appear over-represented among those falling one quintile and persons in the West and South appear overrepresented among those falling two quintiles. Third, persons whose 1984 head was elderly are not over-represented among the absolutely downwardly mobile, but are among the relatively downwardly mobile.

How do the downwardly mobile differ from the other sample members in quantitative terms? Table IV reports the average charac- 
TABLE IV

Comparison of those whose income-to-needs fell 50\% or more to those not downwardly mobile by this measure

\begin{tabular}{lccc}
\hline & $\begin{array}{c}\text { Sample } \\
\text { average }\end{array}$ & $\begin{array}{l}\text { Downwardly } \\
\text { mobile }\end{array}$ & $\begin{array}{l}\text { Not downwardly } \\
\text { mobile }\end{array}$ \\
\hline $\begin{array}{l}\text { Size of 1986 } \\
\text { family unit }\end{array}$ & 3.20 & 2.97 & 3.21 \\
$\begin{array}{l}\text { Change in size } \\
\text { of family unit } \\
\text { (1984 to 1986) }\end{array}$ & -0.09 & -0.33 & $-0.07 *$ \\
$\begin{array}{l}\text { Number of children } \\
\text { in 1986 family }\end{array}$ & 1.12 & 1.10 & 1.12 \\
$\begin{array}{l}\text { Change in number } \\
\text { of children }\end{array}$ & -0.06 & -0.06 & -0.06 \\
$\begin{array}{l}\text { Change in real family } \\
\text { income-to-needs }\end{array}$ & +1.28 & -11.8 & $+2.03 * * *$ \\
$\begin{array}{l}\text { Change in real } \\
\text { family income } \\
\text { (1984 to 1986) }\end{array}$ & $+\$ 1,164$ & $-\$ 31,746$ & $+\$ 3,073 * * *$ \\
$\begin{array}{l}\text { Change in head's } \\
\text { real labor income }\end{array}$ & $-\$ 31$ & $-\$ 18,635$ & $+\$ 1,048 * *$ \\
$\begin{array}{l}\text { Change in wife's } \\
\text { real labor income }\end{array}$ & $+\$ 431$ & $-\$ 2,894$ & $+\$ 624 * * *$ \\
$\begin{array}{l}\text { Change in head }+ \\
\text { wife's real asset } \\
\text { income }\end{array}$ & $+\$ 269$ & $-\$ 7,326$ & $+\$ 710 * *$ \\
$\begin{array}{l}\text { Change in real income } \\
\text { of other members } \\
\text { Change in real } \\
\text { private transfers }\end{array}$ & $+\$ 2,674$ & $+\$ 295$ & $+\$ 2,799 * * *$ \\
$\begin{array}{l}\text { Change in real } \\
\text { public transfers }\end{array}$ & $+\$ 225$ & $+\$ 253$ & $+\$ 26$ \\
\hline
\end{tabular}

* Statistically significant difference at the $90 \%$ level.

** Statistically significant difference at the $95 \%$ level.

*** Statistically significant difference at the $99 \%$ level.

teristics of those whose real family income-to-needs ratio fell by $50 \%$ or more to those not downwardly mobile by this measure. ${ }^{5}$ The average 1986 family size and number of children of the downwardly mobile do not differ significantly from those of the non-downwardly mobile. In 
both groups family size and the number of children decreased slightly from 1984 to 1986 . Apparently family size and the number of children are not driving downward mobility.

The average financial experience of the two groups differs dramatically. The downwardly mobile enjoyed a higher average income in 1984 , $\$ 44160$ versus $\$ 32560$, but then lost an average of $\$ 31746$ by 1986. In contrast, those not downwardly mobile enjoyed a modest average increase of $\$ 3073$ over the period. The average real family income-to-needs ratio of the downwardly mobile fell by nearly 12 , while the ratio of the others increased by 2 .

The largest factor in the decline of family income for the downwardly mobile is the loss of the household head's labor income. This source of income fell on average by $\$ 18635$ in the downwardly mobile group, accounting for the majority of the total decline in real family income. In contrast, the increase in the head's labor income in the nondownwardly mobile group accounts for only about one-third of the total change in their family income.

The decline in the head and wife's asset income accounts for the second largest drop in the income of the downwardly mobile, averaging $\$ 7326$. In contrast, the asset income of the non-downwardly mobile increased by $\$ 710$ on average. Similarly, the labor income of the wife decreased for the downwardly mobile and increased for the others. The income of other family members increased on average for both groups. However, the increase for the downwardly mobile was relatively small.

Both groups received an increase in average public and private transfers from 1984 to 1986 . The increase in transfers to the downwardly mobile totaled $\$ 548$ on average, hardly enough to compensate for their large income losses. Furthermore, the increase in transfers to the downwardly mobile do not significantly differ from the increase received by those who were not downwardly mobile.

In summary, changes in the household head's labor income appear to drive downward mobility. The large drops in the head's labor income may result from a loss in hours worked, a decrease in wages, or a change to a lower-earning head. The transfer system offered little in the way of compensation to the downwardly mobile, the increase in public assistance received was quite small relative to the average earned income loss. 


\section{THE EXTENT AND RISKS OF \\ DOWNWARD INCOME MOBILITY}

The previous section explored who the downwardly mobile are and what has happened to their income. We now consider the extent of downward income mobility. Table $V$ reports the overall frequency, or risk, of downward mobility and then the frequency by group. Again, the calculations for relative downward mobility apply only to sample members initially in the third quintile. Eleven percent of the full sample experienced drops of one-third or more in their family income-to-needs ratio, $5.5 \%$ experienced drops of one-half or more. Nearly one-fifth dropped a quintile and $5.3 \%$ fell two quintiles. ${ }^{6}$

Individuals living in female-headed households face a greater risk of both absolute and relative downward income mobility than do those in male-headed households. In particular, persons in female-headed households are over 1.5 times more likely to drop two quintiles. Those with an elderly 1984 household head appear slightly more at risk of relative downward mobility. Those with a 1984 household head under age 35 appear less likely to suffer either absolute or relative downward mobility.

By racial group, persons whose household head in 1984 was neither African-American nor Caucasian face the greatest risks of absolute downward mobility and of dropping two quintiles. ${ }^{7}$ In fact, their chance of falling two quintiles is over three times greater than that of AfricanAmericans and is six times greater than the risk for Caucasians. Those with African-American heads in 1984 face the highest risk of falling one quintile. Those with a Caucasian head in 1984 face the lowest risk of downward mobility by all four measures. The changes in the distribution of income which occurred over this period seem to have especially hurt racial minorities. Even so, $10 \%$ of those with a Caucasian household head experienced drops of one-third or more in the their income-to-needs ratio and nearly $20 \%$ dropped one quintile.

The frequency of absolute downward mobility does not much vary across the regions of the continental United States. ${ }^{8}$ Regional variation in the risk of relative downward mobility appears somewhat more pronounced. Persons in the South face the greatest risk of dropping one quintile, while those in the North Central region face the lowest. 
TABLE $V$

Frequency of downward mobility

\begin{tabular}{|c|c|c|c|c|}
\hline & \multicolumn{2}{|c|}{ Full Sample } & \multicolumn{2}{|c|}{ Restricted Sample } \\
\hline & $\begin{array}{l}\text { Income- } \\
\text { to-needs } \\
\text { fell by } \\
>33 \%\end{array}$ & $\begin{array}{l}\text { Income- } \\
\text { to-needs } \\
\text { fell by } \\
>50 \%\end{array}$ & $\begin{array}{l}\text { Fell one } \\
\text { quintile }\end{array}$ & $\begin{array}{l}\text { Fell two } \\
\text { quintiles }\end{array}$ \\
\hline All persons & $11.0 \%$ & $5.5 \%$ & $19.2 \%$ & $5.3 \%$ \\
\hline \multicolumn{5}{|l|}{$\begin{array}{l}\text { Gender of } 1984 \\
\text { household head: }\end{array}$} \\
\hline Female & $12.4 \%$ & $5.8 \%$ & $19.2 \%$ & $8.6 \%$ \\
\hline Male & $10.7 \%$ & $5.4 \%$ & $19.2 \%$ & $4.8 \%$ \\
\hline \multicolumn{5}{|l|}{$\begin{array}{l}\text { Age of } 1984 \\
\text { household head: }\end{array}$} \\
\hline 64 or younger & $11.2 \%$ & $4.9 \%$ & $19.0 \%$ & $5.0 \%$ \\
\hline 65 or older & $10.1 \%$ & $5.6 \%$ & $20.6 \%$ & $8.7 \%$ \\
\hline 34 or younger & $10.8 \%$ & $5.5 \%$ & $16.9 \%$ & $4.6 \%$ \\
\hline 35 or older & $11.2 \%$ & $5.5 \%$ & $20.7 \%$ & $5.8 \%$ \\
\hline \multicolumn{5}{|l|}{$\begin{array}{l}\text { Race of } 1984 \\
\text { household head: }\end{array}$} \\
\hline Caucasian & $10.2 \%$ & $5.1 \%$ & $19.1 \%$ & $4.3 \%$ \\
\hline Afro-American & $14.9 \%$ & $7.0 \%$ & $22.5 \%$ & $8.3 \%$ \\
\hline Other & $17.9 \%$ & $9.9 \%$ & $11.2 \%$ & $25.8 \%$ \\
\hline \multicolumn{5}{|l|}{ Child (under age } \\
\hline 14 in 1984) & $10.7 \%$ & $5.6 \%$ & $15.6 \%$ & $4.0 \%$ \\
\hline \multicolumn{5}{|l|}{ Region in 1984: } \\
\hline Northeast & $10.0 \%$ & $4.9 \%$ & $18.2 \%$ & $2.7 \%$ \\
\hline North Central & $10.8 \%$ & $5.6 \%$ & $17.5 \%$ & $5.8 \%$ \\
\hline South & $11.9 \%$ & $5.7 \%$ & $21.9 \%$ & $5.8 \%$ \\
\hline West & $10.8 \%$ & $5.5 \%$ & $19.0 \%$ & $6.8 \%$ \\
\hline $\mathrm{AK}, \mathrm{HI}$ & $22.4 \%$ & $11.9 \%$ & $0.0 \%$ & $25.8 \%$ \\
\hline Foreign & $19.1 \%$ & $0.9 \%$ & $0.0 \%$ & $0.0 \%$ \\
\hline \multicolumn{5}{|l|}{$\begin{array}{l}\text { Marital status } \\
\text { of } 1984 \text { head: }\end{array}$} \\
\hline Married & $10.6 \%$ & $5.4 \%$ & $19.1 \%$ & $4.7 \%$ \\
\hline Single & $10.0 \%$ & $6.4 \%$ & $14.1 \%$ & $2.8 \%$ \\
\hline Widowed & $14.3 \%$ & $5.7 \%$ & $23.7 \%$ & $10.7 \%$ \\
\hline Divorced & $13.3 \%$ & $5.4 \%$ & $20.3 \%$ & $12.7 \%$ \\
\hline Separated & $11.5 \%$ & $5.9 \%$ & $27.0 \%$ & $7.0 \%$ \\
\hline
\end{tabular}




\begin{tabular}{|c|c|c|c|c|}
\hline & \multicolumn{2}{|c|}{ Full Sample } & \multicolumn{2}{|c|}{ Restricted Sample } \\
\hline & $\begin{array}{l}\text { Income- } \\
\text { to-needs } \\
\text { fell by } \\
>33 \%\end{array}$ & $\begin{array}{l}\text { Income- } \\
\text { to-needs } \\
\text { fell by } \\
>50 \%\end{array}$ & $\begin{array}{l}\text { Fell one } \\
\text { quintile }\end{array}$ & $\begin{array}{l}\text { Fell two } \\
\text { quintiles }\end{array}$ \\
\hline \multicolumn{5}{|l|}{$\begin{array}{l}\text { Educational level } \\
\text { of } 1984 \text { head }\end{array}$} \\
\hline Didn't finish HS & $12.5 \%$ & $6.8 \%$ & $27.8 \%$ & $8.9 \%$ \\
\hline High school only & $11.5 \%$ & $4.7 \%$ & $26.0 \%$ & $4.9 \%$ \\
\hline HS + training & $11.6 \%$ & $6.4 \%$ & $12.2 \%$ & $6.3 \%$ \\
\hline Some college & $9.5 \%$ & $4.9 \%$ & $18.2 \%$ & $4.3 \%$ \\
\hline College degree & $8.1 \%$ & $3.6 \%$ & $9.8 \%$ & $0.9 \%$ \\
\hline $\begin{array}{l}\text { Advanced/pro- } \\
\text { fessional degree }\end{array}$ & $11.0 \%$ & $5.2 \%$ & $7.3 \%$ & $5.0 \%$ \\
\hline \multicolumn{5}{|l|}{$\begin{array}{l}\text { Employment status of } \\
1984 \text { household head }\end{array}$} \\
\hline Working & $10.7 \%$ & $5.4 \%$ & $19.5 \%$ & $4.9 \%$ \\
\hline Temp. not working & $26.1 \%$ & $6.3 \%$ & $8.2 \%$ & $23.3 \%$ \\
\hline Unemployed & $13.8 \%$ & $7.3 \%$ & $7.5 \%$ & $11.9 \%$ \\
\hline Retired & $9.4 \%$ & $4.2 \%$ & $22.2 \%$ & $3.0 \%$ \\
\hline Keeping house & $16.1 \%$ & $6.7 \%$ & $6.6 \%$ & $16.9 \%$ \\
\hline Disabled & $9.4 \%$ & $4.3 \%$ & $23.1 \%$ & $5.5 \%$ \\
\hline Student & $12.1 \%$ & $11.3 \%$ & $0.0 \%$ & $9.5 \%$ \\
\hline Workfare, jail, other & $22.9 \%$ & $22.9 \%$ & $0.0 \%$ & $34.1 \%$ \\
\hline \multicolumn{5}{|l|}{ Change in headship: } \\
\hline $\begin{array}{l}\text { Same head } \\
1984 \text { wife became }\end{array}$ & $9.9 \%$ & $4.7 \%$ & $18.7 \%$ & $4.4 \%$ \\
\hline $\begin{array}{l}1986 \text { head } \\
1984 \text { female head }\end{array}$ & $31.6 \%$ & $21.5 \%$ & $46.8 \%$ & $29.8 \%$ \\
\hline $\begin{array}{l}\text { became } 1986 \text { wife } \\
1986 \text { head was }\end{array}$ & $7.1 \%$ & $2.3 \%$ & $22.5 \%$ & $0.5 \%$ \\
\hline $\begin{array}{l}\text { neither head nor } \\
\text { wife in } 1984 \\
\text { Institutionalized }\end{array}$ & $24.7 \%$ & $17.2 \%$ & $18.0 \%$ & $31.7 \%$ \\
\hline $\begin{array}{l}\text { husband in } 1984 \\
\text { returns by } 1986\end{array}$ & $31.0 \%$ & $5.5 \%$ & $29.8 \%$ & $6.1 \%$ \\
\hline
\end{tabular}

Table reads: $11 \%$ of all persons experienced income-to-needs drops of one-third or more. Of those living in female-headed households in 1984, $12.4 \%$ experienced such drops. 
Persons living in the West are the most likely to drop two quintiles and those in the Northeast are the least likely.

Among the marital status categories, persons living with a married or single household head in 1984 face the lowest risks of experiencing declines of $50 \%$ or more in the income-to-needs ratio. They also exhibit the lowest frequencies of dropping two quintiles. However, these groups face fairly high likelihoods of dropping one quintile. Individuals whose 1984 head was divorced or separated generally face higher risks of both types of downward income mobility.

Changes in household headship also influence the risk of downward income mobility. Persons living in a family which retained the same head throughout the sample period generally face lower risks of both absolute and relative downward mobility. Those whose 1984 female head married by 1986 face the lowest risk of absolute downward mobility and of dropping two quintiles. Persons who lived in households in which the 1984 husband and wife split and now live in the family headed by the former wife face the highest risks of both types of downward mobility. This result is consistent with Burkhauser and Duncan's (1989) findings for the 1970s.

The increase in the returns to education appears to have made its mark on the risks of downward income mobility. Those whose household head did not finish high school face the highest risks of both absolute and relative downward mobility. Those living with a collegeeducated household head face lower risks of downward mobility. Even so, $5.2 \%$ of those whose 1984 head held an advanced or professional degree experienced income-to-needs drops of one-half or more and $7.5 \%$ dropped two quintiles.

Living with a working household head in 1984 reduces, but does not eliminate, the probability of downward mobility. Over $5 \%$ of those with working heads experienced drops of $50 \%$ or more in their income-toneeds ratio and $19.5 \%$ fell one quintile. Those whose 1984 household head was unemployed, keeping house, temporarily out of work, or was in Workfare or jail face the highest risks of absolute downward mobility. These persons also face the highest risk of dropping two quintiles. 


\section{LOGIT ANALYSIS OF THE LIKELIHOOD OF DOWNWARD MOBILITY}

The previous sections described who the downwardly mobile are and the extent of downward mobility. These analyses suggest probable causes, but do not formally isolate the factors which contribute to downward income mobility. This section uses Logit analysis to ascertain which of the probable factors significantly influences the likelihood of downward income mobility in a statistical sense. For the sake of brevity we restrict this analysis to the two more severe types of downward mobility: Drops of $50 \%$ or more in the income-to-needs ratio and drops of two or more quintiles down the distribution of real family income. ${ }^{9}$

The descriptive sections of this paper and previous studies of downward income mobility suggest that female headship, changes in family composition, and unemployment of the household head are positively associated with downward mobility. The observed variation in risk across groups suggests that race, age, education, and region may also play significant roles. Obviously, so will the number of children and the number of income earners in the family. The Logit analyses include all of these factors as explanatory variables.

The term "downward mobility" often conjures up the image of a steel or auto factory worker being laid off. Are the downwardly mobile generally blue-collar, production workers? In order to address this question the regressions also include explanatory variables which track the 1984 head's main industry and occupation as measured by three digit codes from the 1970 Census of Population: Alphabetical Index of Industries and Occupations (U.S. Department of Commerce and the Bureau of the Census).

Table VI reports the Logit analysis of the probability of drops of $50 \%$ or more in the income-to-needs ratio. The regression explains a small, but statistically significan proportion of the variation in the log odds of absolute downward income mobility. Education exhibits the expected effect: Living with a 1984 head who had not completed high school raises, while living with a college-educated head lowers, the probability of absolute downward mobility. Living with an elderly head lowers, while living with a young household head raises, the risk. Also 
TABLE VI

Logit analysis of the probability that real family income-to-needs drops $50 \%$ or more

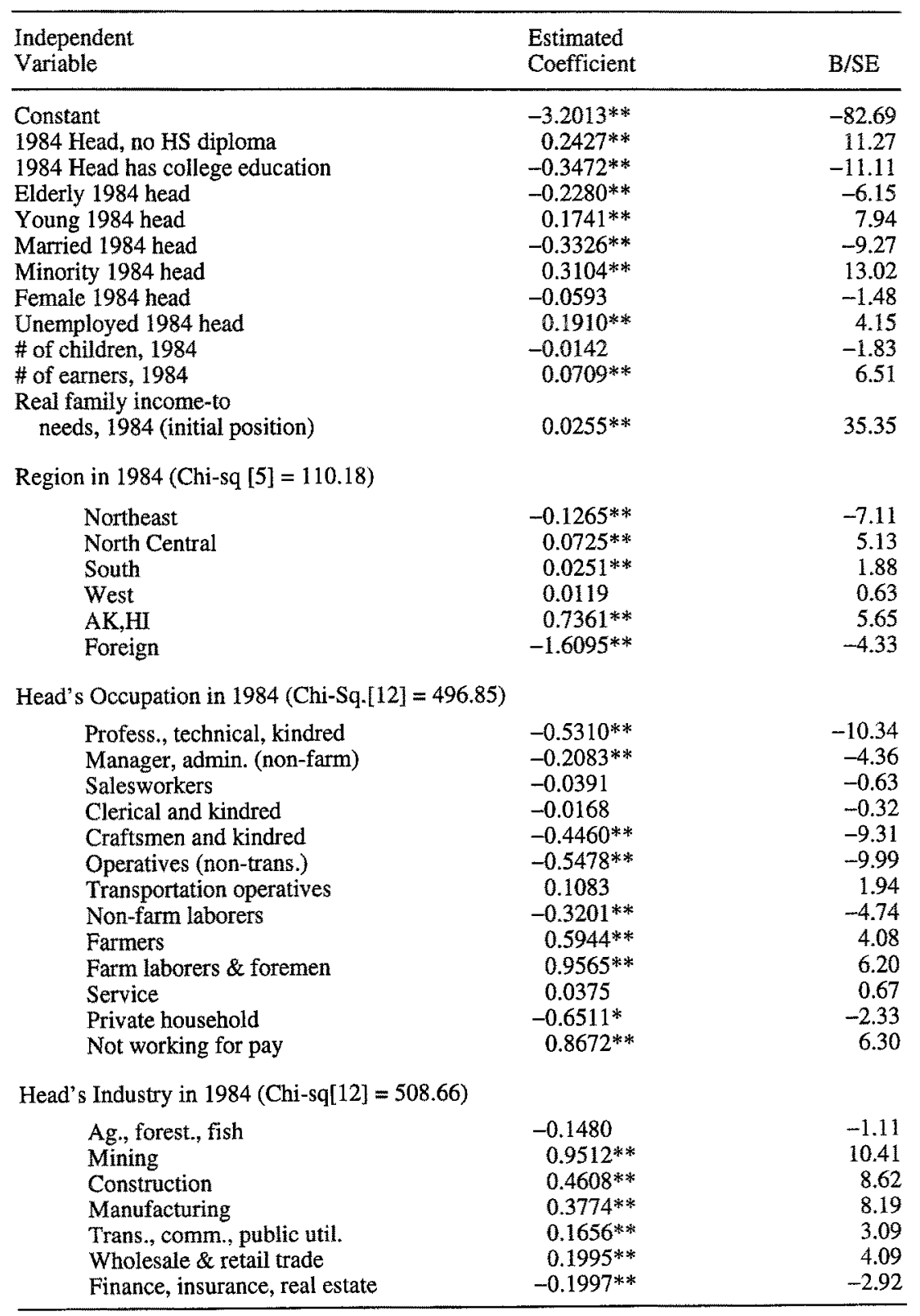


Table VI (Continued)

\begin{tabular}{|c|c|c|}
\hline $\begin{array}{l}\text { Independent } \\
\text { Variable }\end{array}$ & $\begin{array}{l}\text { Estimated } \\
\text { Coefficient }\end{array}$ & $\mathrm{B} / \mathrm{SE}$ \\
\hline Business \& repair services & $0.5973 * *$ & 9.92 \\
\hline Personal services & -0.1254 & -1.28 \\
\hline Entertainment, recreation & $1.0699 * *$ & 12.71 \\
\hline Professional \& related & $0.1214 *$ & 2.33 \\
\hline Public administration & -0.1102 & -1.79 \\
\hline Not working for pay & $-0.7254 * *$ & 5.35 \\
\hline \multicolumn{3}{|l|}{ Headship (Chi-sq[4] $=4825.20)$} \\
\hline Same head $1984 \& 1986$ & $-0.0728 * *$ & -28.42 \\
\hline 1984 wife heads & & \\
\hline 1986 family & $1.6915 * *$ & 53.23 \\
\hline 1984 female head is & & \\
\hline wife in 1986 & $-1.0427 * *$ & -11.80 \\
\hline 1986 head was neither head & & \\
\hline $\begin{array}{l}984 \text { insututionauzed } \\
\text { husband returns by } 1986\end{array}$ & -0.0487 & -0.43 \\
\hline
\end{tabular}

R-squared:

$4.8 \%$

Chi-sq[44]

$7,643.22$

* Statistically significant at $95 \%$ level

*** Statistically significant at $99 \%$ level

as expected, living with an unemployed head increases the likelihood of absolute downward mobility.

Marriage and stable family composition seem to produce financial security. Having a married household head significantly lowers the odds of absolute downward mobility, as does retaining the same head. Furthermore, when a female head marries, the likelihood of downward mobility drops. Lastly, like Duncan (1988) we find that living in a split off family, mainly persons "leaving the nest", increases the likelihood of absolute downward mobility.

While those in female-headed households are disproportionately downwardly mobile, living in a female-headed household does not significantly increase the log odds of absolute downward mobility. In fact, controlling for other factors, female headship exhibits a negative, but statistically insignificant, effect on downward mobility. The absolute increase in average female wages over the period helps explain this 
result. This result suggests that being female in itself does not pose an economic risk, getting divorced does.

This analysis does reinforce the descriptive finding that persons living with a minority household head face higher risks of downward income mobility. Even after controlling for gender, education, employment, region, and initial economic status, living in a minority household significantly raises the likelihood of absolute downward mobility. The structural changes in the economy and the subsequent changes in the distribution of income clearly hurt minorities more.

The regional variable exerts a statistically significant impact on the likelihood of downward mobility. ${ }^{10}$ Specifically, living in the Northeast in 1984 lowers, while living in the South and North Central regions raises the likelihood of absolute downward mobility.

Because the wages and earnings of those already in the lower tail of the distribution have generally fallen, we would expect that those with lower income-to-needs ratios in 1984 would be more likely to be downwardly mobile. However, the results indicate just the opposite: Controlling for the other factors, the higher the 1984 income-to-needs ratio the greater the chance of absolute downward mobility.

Both occupation and industry significantly influence the log odds of absolute downward mobility. Occupations (of the 1984 household head) which lower the likelihood include: Professional, technical, and kindred workers; Non-farm managers and administrators; Craftsmen and kindred workers; Non-transportation operatives; Non-farm laborers; and Private household workers. Only the occupations "Farmers" and "Farm laborers and foremen" significantly raise the odds of absolute downward mobility. This result can likely be traced to the "farm crisis" of the 1980s.

Living with a 1984 household head in the "Finance, insurance and real estate" industry significantly lowers the probability of absolute downward mobility. Industries which significantly raise the likelihood of downward mobility include: Mining; Construction; Manufacturing; Transportation, communication, and other public utilities; Business and repair service; Entertainment and recreation; and Professional and related. The first three of these industries are commonly associated with blue collar jobs. Thus, blue collar workers do indeed appear to be 
susceptible to downward mobility, however they are not alone. The remaining four industries contain many white collar jobs.

Table VII reports the Logit analysis of the probability of dropping two or more quintiles down the distribution of real family income. Again, the regression explains a small, but statistically significant proportion of the variation in the $\log$ odds of downward income mobility. As in the case of absolute downward mobility, living with a college-educated head in 1984 lowers the probability of relative downward mobility. In contrast to the case of absolute downward mobility, living with a 1984 head who had not completed high school lowers the odds of relative downward mobility. The age and marital status variables also exhibit signs which differ from the previous regression. Specifically, having an elderly or married 1984 head raises and having a young head lowers the chances of relative downward income mobility.

The regional effects on both types of downward income mobility appear to be quite similar. The notable exception is that living in the North Central region in 1984 raises the odds of absolute downward mobility, but lowers the odds of relative downward mobility. The occupational categories exhibit the same signs in both regressions with two exceptions. Having a 1984 household head in the "Craftsman and kindred workers" and "Private household workers" categories lowers the probability of absolute, but raises the probability of relative downward mobility. The effects of the various industry categories appear essentially the same in both regressions.

\section{SUMMARY AND CONCLUSIONS}

Between 1984 and 1986 a substantial minority of Americans experienced downward income mobility despite a growing economy: $5.5 \%$ experienced drops of one-half or more in their family income-to-needs ratio and over $24 \%$ fell to a lower quintile in the distribution of real family income. The majority of the downwardly mobile initially lived in households headed by a nonelderly, Caucasian, married, less-educated, working man. Logit analysis indicates that the following factors significantly increase the odds of both absolute and relative downward 
TABLE VII

Logit analysis of the probability of falling two or more quintiles

\begin{tabular}{|c|c|c|}
\hline $\begin{array}{l}\text { Independent } \\
\text { Variable }\end{array}$ & $\begin{array}{l}\text { Estimated } \\
\text { Coefficient }\end{array}$ & $\mathrm{B} / \mathrm{SE}$ \\
\hline Constant & $-3.4419 * *$ & -72.43 \\
\hline 1984 head, no HS diploma & $-0.1248 * *$ & -5.18 \\
\hline 1984 head has college education & $-0.2557 * *$ & -8.55 \\
\hline Elderly 1984 head & $0.2728 * *$ & -6.62 \\
\hline Young 1984 head & $-0.4381 * *$ & -17.14 \\
\hline Married 1984 head & $0.2164 * *$ & 4.82 \\
\hline Minority 1984 head & $0.0761^{* *}$ & 2.71 \\
\hline Female 1984 head & $-0.2594 * *$ & -4.94 \\
\hline Unemployed 1984 head & $0.7457 * *$ & 12.37 \\
\hline \# of children, 1984 & $-0.2116^{* *}$ & -24.44 \\
\hline \# of earners, 1984 & $0.3764 * *$ & 41.33 \\
\hline $\begin{array}{l}\text { Real family income-to } \\
\text { needs, } 1984 \text { (initial position) }\end{array}$ & $0.0201 * *$ & 31.93 \\
\hline \multicolumn{3}{|l|}{ Region in 1984 (Chi-sq $[5]=326.67$ ) } \\
\hline Northeast & $-0.0833 * *$ & -4.75 \\
\hline North Central & $-0.0380^{*}$ & -2.51 \\
\hline South & $0.0289 *$ & 2.03 \\
\hline West & $0.0775^{* *}$ & 3.96 \\
\hline $\mathrm{AK}, \mathrm{HI}$ & $1.6633^{* *}$ & 16.24 \\
\hline Foreign & $0.7220 * *$ & 5.45 \\
\hline \multicolumn{3}{|c|}{ Head's Occupation in 1984 (Chi-sq [12] $=771.65$ ) } \\
\hline Profess., technical, kindred & $-0.1925 * *$ & -4.27 \\
\hline Manager, admin. (Non-farm) & -0.0009 & -0.02 \\
\hline Sales workers & $0.3991^{* *}$ & 7.51 \\
\hline Clerical and kindred & $0.1379 * *$ & 2.76 \\
\hline Craftsmen and kindred & $0.1217^{* *}$ & 2.95 \\
\hline Operatives (non-trans.) & $-0.1865^{* *}$ & -3.57 \\
\hline Transportation operatives & $0.7901^{* *}$ & 16.42 \\
\hline Non-farm laborers & $-0.2347 * *$ & -3.36 \\
\hline Farmers & $2.2085^{* *}$ & 4.54 \\
\hline Farm laborers \& foremen & $3.4490^{* *}$ & 7.03 \\
\hline Service & 0.0269 & 0.48 \\
\hline Private household & $1.4687 * *$ & -3.19 \\
\hline Not working for pay & $-0.4457 * *$ & -4.13 \\
\hline \multicolumn{3}{|c|}{ Head's Industry in 1984 (Chi-sq $[12]=381.33$ ) } \\
\hline Ag., forest., fish & $-2.9695 * *$ & -6.26 \\
\hline Mining & $0.7032 * *$ & 7.81 \\
\hline Construction & $0.1509 * *$ & 3.07 \\
\hline Manufacturing & $0.1912^{* *}$ & 4.73 \\
\hline Trans., comm., public util. & $0.3770^{* *}$ & 8.21 \\
\hline Wholesale \& retail trade & $0.1473 * *$ & 3.38 \\
\hline Finance, insurance, real estate & $-0.4296 * *$ & -6.55 \\
\hline
\end{tabular}


Table VII (Contimued)

\begin{tabular}{|c|c|c|}
\hline $\begin{array}{l}\text { Independent } \\
\text { Variable }\end{array}$ & $\begin{array}{l}\text { Estimated } \\
\text { Coefficient }\end{array}$ & $\mathrm{B} / \mathrm{SE}$ \\
\hline Business \& repair services & $0.4735^{* *}$ & 8.44 \\
\hline Personal services & $-2.1418 * *$ & -7.47 \\
\hline Entertainment, recreation & $0.5324 * *$ & 6.02 \\
\hline Professional \& related & $0.2857 * *$ & 6.16 \\
\hline Public administration & 0.0694 & 1.26 \\
\hline Not working for pay & -0.0352 & -0.34 \\
\hline \multicolumn{3}{|l|}{ Headship (Chi-sq $[4]=6076.58$ ) } \\
\hline Same head $1984 \& 1986$ & $-0.1251^{* *}$ & -51.97 \\
\hline $\begin{array}{l}1984 \text { wife heads } \\
1986 \text { family }\end{array}$ & $15865 * *$ & \\
\hline 1984 female head is & $1.5803^{2}$ & 48.04 \\
\hline wife in 1986 & $0.3965 * *$ & 4.92 \\
\hline $\begin{array}{l}1986 \text { head was neither head } \\
\text { nor wife in } 1984\end{array}$ & $17249 * *$ & 5958 \\
\hline 1984 institutionalized & & \\
\hline husband returns by 1986 & $1.3676 * *$ & 18.76 \\
\hline
\end{tabular}

R-squared:

Chi-sq[44]

$8.7 \%$

$14,732.31$

* Statistically significant at $95 \%$ level

** Statistically significant at $99 \%$ level

income mobility: Male headship; minority headship; marital dissolution; nest-leaving; unemployment of the household head; having a household head who is a farmer or farm laborer; having a household head in the trade, mining, construction, or manufacturing industries, and having a higher initial ratio of income-to-needs. The following factors significantly lower the odds of downward income mobility: Having a collegeeducated head; retaining the same household head; having a household head in a professional, technical, or operative occupation; and having a head in the finance, insurance, and real estate industry.

The results suggest that education and labor market changes play critical roles in downward income mobility. Policies which curb the high school drop rate and encourage college attendance may help reduce downward mobility. Macroeconomic growth policies, especially those which enhance employment opportunities for young men, and training and relocation programs might also help reduce downward mobility. 


\section{ACKNOWLEDGEMENTS}

The author thanks Greg Duncan and Debra Laren for their assistance with this project.

\section{NOTES}

1 However, the size of the gains over the income distribution was somewhat unequal. Those at the top gained more than did those on the bottom.

2 Validity studies of the PSID generally confirm that the weighted sample is representative and that measurement errors in annual earnings are low (Bound et al., 1989). For validity studies see Duncan and Hill (1989), Lillard and Waite (1989), and Becketti et al. (1988). For general information about the PSID see Hill (1992).

3 Real family income includes the labor earnings of all members, dividends, rent, interest, and public and private transfers. The family income-to-needs ratio is calculated by dividing real family income by the official poverty line (in real terms) for the family's size. We use the CPI-U-X1 to convert nominal income and need standards to real terms.

${ }^{4}$ Using a drop of one quintile to measure downward mobility may overstate the severity of the drop. For example, if initial family income exceeds the quintile break by one dollar, the loss of $\$ 1.01$ in income would constitute a drop of 1 quintile.

5 Because the PSID is a stratified and clustered sample the standard errors automatically generated by most software packages will not be correct. The tests reported in this table are based on corrected standard errors generated by the PSALMS routine in OSIRIS.

6 Some of the observed downward mobility may be transitory.

7 The "Other" group includes Native Americans, Asians, and Pacific Islanders.

${ }^{8}$ We omit discussion of risk differences for Alaska, Hawaii, and foreign counties as less than $1 \%$ of the sample resides in these regions.

9 This analysis uses the full sample rather than only persons initially in the third quintile. We include the 1984 family income-to-needs ratio to control for the effect of initial position.

10 The coefficients reported for all of categorical variables are standardized to reflect deviations from the category's mean effect.

\section{REFERENCES}

Becketti, S., W. Gould, L. Lillard and F. Welch: 1988, 'The PSID after fourteen years: an evaluation', Journal of Labor Economics 6(4), pp. 472-492.

Bound, J. and G. Johnson: 1992, 'Changes in the structure of wages during the 1980s: an evaluation of alternative explanations', American Economic Review 83(3), pp. $371-392$.

Bound, J., C. Brown, G. Duncan and W. Rodgers: 1989, "Measurement error in crosssectional and longitudinal labor market surveys: results from two validation studies', Working Paper 2884, National Bureau of Economic Research.

Burkhauser, R. and G. Duncan: 1989, 'Economic risks of gender roles: income loss and life events over the life course', Social Science Quarterly 70(1), pp. 3-23.

Burtless, G.: 1990, A Future of Lousy Jobs? The Changing Structure of Wages (The Brookings Institution, Washington D.C.). 
Burtless, G.: 1991, 'Growing inequality in pre-tax income and earnings', Testimony for the House Budget Committee, July 17.

Cancian, M., S. Danziger and P. Gottschalk: 1993, 'The changing contributions of men and women to the level and distribution of family income', in D. Papadimitriou and E. Wolff (eds.), Poverty and Prosperity at the Close of the Twentieth Century (MacMillan, New York).

Dentzer, S.: 1991, 'The vanishing dream', U.S. News \& World Report, April 22, pp. $39-43$.

Duncan, G.: 1988, 'The volatility of family income over the life course', in P. Baltes, D. Featherman and R. Lerner (eds.), Life-Span Development and Behavior, v. 9 (Lawrence Erlbaum Associates, Publishers, Hillsdale, N. J.).

Duncan, G., R. Coe, M. Corcoran, M. Hill, S. Hoffman and J. Morgan: 1984, Years of Poverty, Year of Plenty (Institute for Social Research, Ann Arbor).

Duncan, G. and D. Hill: 1989, 'Assessing the quality of household panel data: the case of the panel study of income dynamics', Journal of Business \& Economic Statistics $7(4)$, pp. $441-452$.

Duncan, G., T. Smeeding and W. Rodgers: 1991, 'W(h)ither the middle class? a dynamic view', mimeo, Survey Research Center, Institute for Social Research, Ann Arbor.

Ehrenreich, B.: 1989, Fear of Falling: The Inner Life of the Middle Class (Pantheon Books, New York)

Hill, M.: 1992, The Panel Study of Income Dynamics: A User's Guide (Sage Publications, Newbury Park, Ca.).

Juhn, C., K. Murphy and B. Pierce: 1990, 'Wage inequality and the rise in returns to skill', mimeo, University of Chicago.

Karoly, L.: 1993, 'The trend in inequality among families, individuals, and workers in the United States: A twenty-five year perspective, in S. Danziger and P. Gottschalk (eds.), Uneven Tides: Rising Inequality in the 1980s (Russell Sage Foundation, New York).

Katz, L. and K. Murphy: 1992, 'Changes in relative wages, 1963-1987: supply and demand factors', The Quarterly Journal of Economics 107(1). pp. 35-78.

Levy, F.: 1987, Dollars and Dreams: The Changing American Income Distribution (Russell Sage Foundation, New York).

Levy, F. and R Michel: 1991, The Economic Future of American Families: Income and Wealth Trends (The Urban Institute, Washington D.C.).

Levy, F. and R. Murnane: 1992, 'U.S. earnings levels and earnings inequality: a review of recent trends and proposed explanations', Journal of Economic Literature 30 , pp. $333-381$.

Lillard, L. and L. Waite: 1989 , 'Panel versus retrospective data on marital histories: lessons from the PSID', in H. V. Beaton, D. A. Ganni and D. T. Frankel (compilers), Individuals and Families in Transition: Understanding Change through Panel Data (U.S. Bureau of the Census, Washington D.C.).

Newman, K.: 1988, Falling from Grace: The Experience of Downward Mobility in the American Middle Class (MacMillan, London).

Strobel, F.: 1993, Upward Dreams, Downward Mobility (Rowmann \& Littlefield Publishers, Lanham, Maryland).

Thurow, L.: 1987, 'The disappearance of the middle class', The New York Times, Feb. 5.

\section{Department of Social Sciences,}

University of Michigan, Dearborn,

Dearborn MI, 48128-1491,

U.S.A. 